\title{
THE INFLUENCE OF TAX AND EXPENDITURE POLICIES ON ECONOMIC GROWTH IN THE NETHERLANDS: AN EMPIRICAL ANALYSIS**
}

BY

ED W.M.T. WESTERHOUT AND JARIG VAN SINDEREN*

\section{INTRODUCTION}

The rate of economic growth in The Netherlands has fallen from an average of nearly six percent a year in the sixties to a poor two percent a year in the eighties. Popular culprits are the slowdown in structural productivity growth, the oil price shocks in the seventies, and, last but not least, the expansion of the public sector, manifesting itself in huge levels of taxation and public debt.

This paper discusses the influence of government policies and external factors on economic growth in The Netherlands over the past twenty-five years. In particular, it considers the effectiveness of government tax and expenditure policies and the impact of external developments. Furthermore, it examines which part of the recovery in the eighties can be attributed to demand and supply factors. It focusses on some major variables, namely output, employment, capital accumulation and the share of labour income in output.

The paper employs a small linearized macroeconomic model that has been estimated, using annual data, for the period 1958-1989. While this analysis fits well into a tradition of empirical examinations of the Dutch economy (e.g. Rutten (1985a, 1985b), Van Sinderen and Mulder (1988) and Van Sinderen (1993)), the model it uses is considerably smaller than most models of the Dutch economy. In contrast to these empirical examinations, however, the present paper attaches considerable weight to supply-side elements. In modelling taxes and social security contributions, it incorporates, apart from the effects on aggregate demand, the supply-side effects and the forward shifting of taxes and social security contributions into wages. Next, public expenditure is subdivided into

* At the moment of writing, Ed W.M.T. Westerhout was a staff member of the Directorate for Economic Policy, Ministry of Economic Affairs. Currently he is affiliated to the Central Planning Bureau, P.O. Box 80510, 2508 GM The Hague. Jarig van Sinderen is Deputy Director of the Directorate for Economic Policy, Ministry of Economic Affairs, P.O. Box 20101, 2500 EC The Hague and Professor of Economic Policy at the Research Centre for Economic Policy (OCFEB), Erasmus University, P.O. Box 1738, 3000 DR Rotterdam.

** We thank Peter van Bergeijk, Lans Bovenberg, Rob Mulder, Pieter Waasdorp, and two anonymous referees for useful suggestions and comments. 
public consumption and public investment. Furthermore, the model incorporates elements of the new growth theory which focusses, among other things, on the impact of government policies on the rate of economic growth (Romer (1986), Barro (1990), King and Rebelo (1990)). Consequently, the model seems to be the right tool to evaluate economic policies in The Netherlands in the eighties which were partly motivated by supply-side considerations. The role of government deficits and public debt is not discussed explicitly. Except for the impact upon the formulation of policy strategies, there is no evidence that the budget deficit and the public debt position in The Netherlands have had a significant impact on economic development (Bomhoff (1991)).

The paper is structured as follows. Section two discusses the specification of the equations to be estimated. Section three presents the estimation results. Section four deals with the calculations of the influence of various policy and external variables on output, employment, capital accumulation and the labour share in output. Finally, section five draws conclusions.

\section{SPECIFICATION OF MODEL EQUATIONS}

This section discusses the specification of the equations to be estimated for output, employment, capital accumulation and the share of labour in output. All four equations are semi-reduced-form equations: Although they result from substituting several structural equations into each other, some of the explanatory variables are endogenous.

\subsection{The Output Equation}

We model output as a weighted average of the demand and supply of goods and services. ${ }^{1}$ This modelling device reflects the assumption that the market for goods and services may be in disequilibrium. Indeed, there are several arguments for the existence of short-run disequilibria. ${ }^{2}$

Let us first derive the supply equation. The supply of goods and services, or the production capacity, is modelled by using a constant-returns-to-scale CES production function. Formulating this production function in growth rates, one obtains $^{3}$ :

$$
\dot{y}^{s}=\alpha \cdot \dot{l}^{\prime \prime}+(1-\alpha) \cdot \dot{k}+\pi_{y} \quad 0<\alpha<1
$$

where $y^{s}, l^{\prime \prime}, k$ and $\pi_{y}$ denote the production capacity, the labour potential, the capital stock and the rate of Hicks-neutral technical progress, respectively. Next,

1 See Siebrand (1979) and Kooiman (1986) for a discussion of this modelling device in terms of disequilibrium theory.

2 See Stevenson et al. (1988) for a review.

3 A dot above a variable denotes a growth rate. 
$\alpha$ and $1-\alpha$ denote the output elasticities of labour and capital, respectively. Labour potential growth is defined as the sum of the growth of the capacity demand for labour, $l^{\prime}$, and the rate of change of some quality index for labour, $\pi_{l}$ :

$$
\dot{l}^{\prime \prime}=\dot{l}^{\prime}+\pi_{l}
$$

We model capital as a homogeneous production factor. With a CES production function, the following relation holds for the ratio of labour potential to the capital stock:

$$
\dot{l}^{\prime \prime}-\dot{k}=-\beta \cdot\left[\left(\dot{p}_{l}-\pi_{l}\right)-\dot{p}_{k}\right] \quad \beta>0
$$

with $p_{l}$ : wage rate

$p_{k}:$ cost of capital

$\beta$ : elasticity of substitution between labour and capital

Assuming that labour and capital are initially rewarded according to their marginal products, that actual production equals production capacity, and that employment equals capacity demand for labour, this relationship can be formulated as follows:

$$
\dot{l}^{\prime \prime}=\dot{k}-\beta^{\prime} \cdot \dot{a i q}
$$

with $\beta^{\prime}=\beta /[(1-\alpha) \cdot(1-\beta)]$

aiq: labour share in output

Since time series of sufficient length for the capital stock are not available, the growth rate of capital is replaced with the gross investment rate, using

$$
\dot{k}=\Delta k / k_{-1}=\left(i-\delta_{k} \cdot k_{-1}\right) / k_{-1}=1 / \kappa \cdot i / y_{-1}-\delta_{k}
$$

with $i$ : gross investment

$$
\begin{aligned}
& y: \text { output } \\
& \delta_{k}: \text { capital depreciation rate } \\
& \kappa: \text { capital-output ratio }
\end{aligned}
$$

As to the rate of technological progress, we assume that it is a negative function of the size of the public sector, or

$$
\pi_{y}=-c s+\underline{\pi}_{y}
$$

with $c s$ : impact of the size of the public sector

$\pi_{y}$ : exogenous component of technological progress 
Specification (6) is based on endogenous growth theory which suggests that the size of the public sector may not only explain the level of output, but also its rate of growth (see e.g. King and Rebelo (1990)). Implicit is the assumption that the size of the public sector indicates the level of public consumption rather than public investment. As consumption makes up a large part of government expenditure in The Netherlands, this does not seem to be an unreasonable assumption.

Substitution of (4), (5) and (6) into (1) yields

$$
\dot{y}_{s}=1 / \kappa \cdot i / y_{-1}-\alpha \cdot \beta^{\prime} \cdot a \dot{i q}-c s+\underline{\pi}_{y}-\delta_{k}
$$

As to the determination of effective demand, we relate exports to world trade and the terms of trade and imports to output and the terms of trade. Private consumption and investment are assumed to be negative functions of the interest rate and to be dependent on the business cycle. Finally, public expenditure is exogenous. To sum up, we postulate the following demand equation:

$$
\dot{y}^{d}=\delta_{1} \cdot \dot{m w}-\delta_{2} \cdot \dot{t o t}-\delta_{3} \cdot \dot{r}+\delta_{4} \cdot \dot{a}+b c \quad \delta_{i}>0 \quad i=1, \ldots, 4
$$

with $y^{d}$ : effective demand

$m w$ : world trade

tot : terms of trade

$r$ : real interest rate

$a$ : government expenditure

$b c$ : impact of the business cycle

Taking actual production to be a weighted average of supply and demand, with weights $\varepsilon$ and $1-\varepsilon(0<\varepsilon<1)$, the output equation to be estimated reads:

$$
\begin{aligned}
\dot{y}= & \varepsilon / \kappa \cdot i / y_{-1}-\varepsilon \cdot \alpha \cdot \beta^{\prime} \cdot a \dot{a} q-\varepsilon \cdot c s+(1-\varepsilon) \cdot \delta_{1} \cdot \dot{m w}-(1-\varepsilon) \cdot \delta_{2} \cdot \dot{t o t} \\
& -(1-\varepsilon) \cdot \delta_{3} \cdot \dot{r}+(1-\varepsilon) \cdot \delta_{4} \cdot \dot{a}+(1-\varepsilon) \cdot b c+\varepsilon \cdot \underline{\pi}_{y}-\varepsilon \cdot \delta_{k}
\end{aligned}
$$

\subsection{The Employment Equation}

Analogous to output, employment is considered a weighted average of demand and supply. Capacity demand for labour is determined by the development of production capacity. The equation for the capacity demand for labour derives from (2) and (4):

$$
i^{\prime}=\dot{k}-\beta^{\prime} \cdot \dot{a i q}-\pi_{l}
$$

We assume lags in the adjustment of actual demand for labour, $l^{d}$, to its capacity demand. Immediate adjustment is precluded by adjustment costs. In case of a recession, for example, it can be rational due to adjustment costs not to fully 
utilize production capacity for a while instead of reducing capacity. Hence, the business cycle may have an impact on employment growth. Furthermore, labour market rigidities and the quantity and quality of labour supply may have an impact on the speed of adjustment. We assume the following partial adjustment process:

$$
i^{d}=i_{-1}^{d}+\theta \cdot\left(\dot{l}^{\prime}-\dot{l}_{-1}^{d}\right)+b c \quad 0<\theta<1
$$

Labour supply, $l^{s}$, is considered to be a function of the size of the population, $p o p$, and the wage rate net of taxes and social security contributions, $p_{l n}$ :

$$
\dot{l}^{s}=\zeta_{1} \cdot \dot{p o p}-\zeta_{2} \cdot \dot{p}_{l n} \quad \zeta_{1}, \zeta_{2}>0
$$

Using (10), (11), (12) and (15), and denoting the weights of labour demand and labour supply by $\eta$ and $1-\eta(0<\eta<1)$ respectively, the following specification for employment results:

$$
\begin{aligned}
\dot{l}= & \eta \cdot(1-\theta) \cdot \dot{l}_{-1}^{d}+\eta \cdot \theta / \kappa \cdot i / y_{-1}-\eta \cdot \theta \cdot \beta^{\prime} \cdot \dot{a i q}-\eta \cdot \theta \cdot \pi_{l} \\
& -\eta \cdot \theta \cdot \delta_{k}+\eta \cdot b c+(1-\eta) \cdot \zeta_{1} \cdot p o p-(1-\eta) \cdot \zeta_{2} \cdot \dot{p}_{l n}
\end{aligned}
$$

\subsection{The Capital Accumulation Equation}

Capital accumulation is described by the following equation:

$$
\dot{k}=(1-\sigma / \kappa) \cdot \dot{k}_{-1}+\sigma / \kappa \cdot \dot{i}
$$

with $\sigma$ : gross investment ratio.

Expressing the rate of capital accumulation again in terms of the gross investment rate, this equation reads:

$$
i / y_{-1}=(1-\sigma / \kappa) \cdot\left(i / y_{-1}\right)_{-1}+\sigma \cdot \dot{i}+\sigma \cdot \delta_{k}
$$

We assume investment to be determined by a number of factors. First, we postulate a positive relation between investment and after-tax profit income. On the one hand, current income feeds expectations about future profit income, while on the other hand it acts as a source of finance. Second, we assume that investment is influenced by the business cycle.

To capture the flavour of a favourable investment climate, we assume private investment is a negative function of some marginal tax and social security contribution rate. Furthermore, private investment is taken to be a positive function of public investment. This draws on the assumption that private and public investment are complementary. ${ }^{4}$ In addition, we include a cost-of-capital 
variable and some monetary aggregates as investment may depend on financing conditions. Hence, the capital accumulation equation to be estimated reads as follows:

$$
\begin{aligned}
i / y_{-1}= & (1-\sigma / \kappa) \cdot\left(i / y_{-1}\right)_{-1}+\sigma \cdot \lambda_{1} \cdot y \dot{k^{\prime}} b+\sigma \cdot b c+\sigma \cdot t s c+\sigma \cdot \lambda_{2} \cdot \dot{i g} \\
& -\sigma \cdot \lambda_{3} \cdot \dot{p}_{k}+\sigma \cdot m o n+\sigma \cdot \delta_{k} \quad \lambda_{1}, \lambda_{2}, \lambda_{3}>0
\end{aligned}
$$

with $y k^{\prime} b$ : disposable profit income

tsc : tax and social security contribution rate

ig : public investment

mon: monetary aggregate

\subsection{The Labour Share Equation}

The labour share equation is derived from the wage equation. In modelling the wage equation, it is assumed that there is full and immediate price indexation as well as full and immediate adjustment to changes in labour productivity. Furthermore, forward shifting of taxes and social security contributions is included as well as the tension on the labour market, the so-called Phillips curve:

$$
\dot{p}_{l}=\dot{p}^{*}+\dot{h}^{*}+a f w+p h c
$$

with $p^{*}$ : price index

$h^{*}$ : labour productivity index

afw: forward-shifting variable

phe: Phillips curve

The price index is a weighted average of the price of consumption and the price of production:

$$
\dot{p}^{*}=\mu \cdot \dot{p}_{c}+(1-\mu) \cdot \dot{p}_{y} \quad 0<\mu<1
$$

with $p_{c}$ : price of consumption

$p_{y}:$ price of production

The labour productivity index is a weighted average of two indicators of labour productivity growth, the first one being a moving average of labour productivity growth and the second one the current growth in labour productivity:

$$
\dot{h}^{*}=v \cdot \dot{h}_{t r}+(1-v) \cdot \dot{h} \quad 0<v<1
$$

with $\dot{h}_{t r}$ : moving average of labour productivity growth

$\dot{h}:$ current labour productivity growth 
Substituting (18) and (19) into (17) and using the definition for the labour share in output, the equation for the labour share in output reads:

$$
\text { aiq }=\mu \cdot\left(\dot{p}_{c}-\dot{p}_{y}\right)+v \cdot\left(\dot{h}_{t r}-\dot{h}\right)+a f w+p h c
$$

\section{ESTIMATION RESULTS}

Having specified the equations for output, employment, investment, and the labour share in output, we now estimate equations (9), (13), (16) and (20). Due to simultaneity of the equations, we use the two-stage least-squares estimation procedure. The estimation period runs from 1958 to 1989. In estimating, several variables are lagged in order to obtain an estimation result which combines significant coefficients with a reasonable degree of explanation. However, in those cases where it is theoretically unlikely that long lags occur, only specifications with current or shortly-lagged variables are considered. We present the estimation results for the four equations and discuss them in turn. Sources of the data that have been used are described in Westerhout and Van Sinderen (1992). The figures in parentheses under the coefficients refer to the corresponding $t$-values.

Output

$$
\begin{aligned}
& \dot{y}=0.48 i / y_{-1}-0.50 a i q_{-1 / 4}+0.32 m w+0.19 \dot{a} \\
& \begin{array}{llll}
(4.71) \quad(5.58) \quad(7.44) \quad(6.06)
\end{array} \\
& -0.002 \dot{r}_{-3 / 2}+0.46 \Delta \dot{l}_{-1}-0.14 t y-3.51 \\
& \begin{array}{llll}
(2.94) \quad(4.45) \quad(2.84) \quad(1.59)
\end{array} \\
& D W=2.21 \quad \bar{R}^{2}=0.95
\end{aligned}
$$

with $t y: \operatorname{tax}$ burden (tax receipts in terms of national income)

As equation (21) shows, the terms of trade is not included in the output equation, because it did not contribute significantly to output growth. The business cycle is represented by the acceleration of employment growth. In addition, the size of the public sector is represented by the tax burden. We also estimated the output equation with the size of the public sector represented by the ratio of the total of taxes, social security contributions and non-tax receipts to income. These estimations, however, did not produce significant coefficients as to the impact of the size of the public sector. 
Employment

$$
\begin{aligned}
& \dot{i}=0.87 \dot{l}_{-1}+0.13 i / y_{-1}-0.24 a i q_{-5 / 4}+0.07 m d r_{-5 / 4} \\
& \text { (7.78) (2.16) (4.65) (3.23) } \\
& -0.10 u \dot{b}-3 / 4+0.09 \Delta z \dot{i e k} k_{-1 / 4}+0.18 \Delta \dot{y}_{-1 / 4}-2.47 \\
& \text { (5.10) } \\
& D W=1.77 \quad \bar{R}^{2}=0.87
\end{aligned}
$$

$m d r$ : marginal tax and social security contribution rate of employees $u b$ : number of productive hours per worker in the construction sector ziek: absenteeism due to illness

Estimating the employment equation, the population variable and the wage rate turned out to be insignificant. Consequently, the employment equation reduces to a labour demand equation $(\eta=1)$. In equation (22), the marginal tax and social security contribution rate on employees' labour income is included as an explanatory variable. ${ }^{5}$ This variable is assumed to exert a negative impact on the motivation and productivity of workers and, consequently, to have a positive impact upon labour demand. While it is true that the tax and social security contribution rate may also exert a negative impact on employment through its effect on labour supply, this effect is not found in (22) as the employment equation is a labour demand equation.

We also estimated the employment equation using the wedge - the total of taxes and social security contributions paid by employers and employees instead of the marginal tax and social security contribution rate on employees' labour income. This did not produce a plausible regression equation, however. Next to the tax and social security contribution rate, the number of productive hours in the construction sector and an index of absenteeism due to illness are included as proxies of labour quality. The acceleration of output growth reflects the impact of the business cycle.

The parameter that measures the speed of adjustment of employment to labour demand, $\theta$, is seen to be estimated at 0.13 . This suggests that labour market rigidities are significant. ${ }^{6}$

5 See also Rutten (1985a).

6 Intuitively, this parameter value seems to underestimate the actual speed of adjustment of employment. This is also suggested by the figure of 0.39 that is found by Krapels et al. (1989) as parameter value for the adjustment of employment. 
Investment

$$
\begin{aligned}
& i / y_{-\mathrm{I}}=0.78\left(i / y_{-1}\right)_{-1}+0.06 y \dot{k^{\prime} b_{-1}}+0.26 \Delta \dot{y}-0.13 \dot{m d} r_{-1 / 2} \\
& \text { (11.39) (2.86) (5.20) (4.00) } \\
& +0.05 \dot{i g}_{-2}-0.04 \dot{p}_{k-2}+0.06 \dot{m}+0.13 m y_{-1}+0.10 \\
& \begin{array}{llll}
(3.29) \quad(2.37) \quad(2.09) \quad(2.80) \quad(0.08)
\end{array} \\
& D W=2.61 \quad \bar{R}^{2}=0.91
\end{aligned}
$$

$m$ : money, defined as the amount of primary liquidities $m y$ : ratio of money to national income

The cost of capital in (23) has been calculated on the basis of the formula in Hall and Jorgenson (1971). ${ }^{7}$ The acceleration of output growth acts as the index of the business cycle. The marginal tax and social security contribution rate on labour income appears to have a significant negative impact on investment. Finally, it appears that both the growth of liquidities and the liquidity ratio exert a significant positive impact upon investment.

Labour share in output

$$
\begin{aligned}
& \dot{a i q}=0.51\left(\dot{p}_{c}-\dot{p}_{y}\right)+0.77\left(\dot{h}_{t r}-\dot{h}\right)+0.62 \Delta g d r \\
& \text { (2.41) (7.08) (4.90) } \\
& +1.35(1 / w)_{-5 / 4}-0.89 \Delta w_{-1}-0.81 \\
& \text { (3.76) } \\
& D W=2.39 \quad \bar{R}^{2}=0.85 \\
& \dot{h}_{t r}=0.3 \dot{h}+0.3 \dot{h}_{-1}+0.2 \dot{h}_{-2}+0.2 \dot{h}_{-3} \\
& g d r \text { : average tax and social security contribution rate of employees } \\
& w \text { : unemployment rate }
\end{aligned}
$$

From the above regression equation it can be seen that only the taxes and social security contributions paid by employees are shifted forward. Estimates of the forward shifting of social security contributions paid by employers turned out to be insignificant. Furthermore, both the level of unemployment and the change with respect to the preceding year are included as explanatory variables, representing the strong and the weak Phillips mechanism, respectively.

7 Alternatively, the cost of capital can be calculated using data on output, the labour share in output, and the capital stock, corresponding to the definition of the cost of capital implied by equation (3). As data for the capital stock are unavailable, we chose not to use this approach, but, instead, to use the formula in Hall and Jorgenson (1971). 
The regression equation shows that the price of consumption and the price of production have about equal weights in the price index. The labour productivity index is heavily based on permanent labour productivity growth, namely for $77 \%$. The coefficient of the forward-shifting variable amounts to $62 \%$. This figure is rather high when compared to other estimates. ${ }^{8}$

Combining the four equations, the coefficients from the structural equations can be identified. The elasticities of output with respect to labour and capital, $\alpha$ and $1-\alpha$, amount to 0.56 and 0.44 , respectively. The elasticity of substitution in production, $\beta$, equals 0.45 . This justifies a CES-type production function instead of a Cobb-Douglas-type of production function. ${ }^{9}$ The weights of demand and supply in the output equation, $\varepsilon$ and $1-\varepsilon$, equal 0.48 and 0.52 , respectively. The capital-output ratio seems rather low, namely $1.00 .{ }^{10}$

\section{CONTRIBUTION CALCULATIONS}

Having described the model, we can calculate the contributions of the exogenous variables to the explanation of the endogenous variables, namely output and employment growth, the investment rate and the labour share in output. We divide the simulation period into three periods of eight years: 1966-1973, 1974-1981 and 1982-1989. Roughly speaking, we are dealing with three phases: a period of prosperity, one of economic downturn and a period of recovery. The regression technique only provides information about the contributions of the exogenous variables to the variance of the endogenous variables. Consequently, the average growth rate of output and employment and the level of the investment rate and the labour share in output remain unexplained.

In calculating contributions of exogenous to endogenous variables, several variables have to be endogenized and, if necessary, linearized. In particular, we express disposable profit income in terms of output, the labour share in output, and the rate of profit taxation, $v p b .{ }^{11}$ Furthermore, current and permanent labour productivity growth can be written in terms of output and employment growth. Finally, unemployment can be expressed in terms of labour supply, as, employment in the private sector and employment in the public sector, ag.

We divide the exogenous variables into three groups. The first group concerns government policy. This group contains government expenditure, public invest-

8 Fase et al. (1990) contains a review of some Dutch models on this point.

9 This figure is comparable to the estimates in Broer (1981) - who derives a value for labour-capital substitution of 0.46 - and Kuipers et al. (1988) - who estimate this elasticity to be about 0.25 .

10 See Westerhout and Van Sinderen (1992) for a discussion of the stability of the equations and the model's forecast quality.

11 We define after-tax profit income, $y k^{\prime} b$, as $y \cdot(100-a i q) \cdot(100-v p b)$. In practice, corporate taxes are levied on income after deduction of interest payments and capital depreciation allowances. However, estimations using the variable as defined above yielded more significant regression coefficients. 
ment, the number of civil servants, tax and social security contribution variables, the cost-of-capital variable, and, finally, the monetary variables. The second group, labeled external, consists of foreign variables and domestic variables that cannot be considered part of government policies. This group comprises labour supply, the incidence of illness, the differential between consumption and output inflation, the interest rate, world trade, and, finally, the number of productive hours per worker. This classification is rather arbitrary: Some of the variables characterized as exogenous are in fact affected by both government policy and other influences. For example, the differential between the rate of increase of the price of consumption and the price of output reflects changes in exchange rates and in the amount of indirect taxation.

The third group, labeled rest, contains the impact of the development of endogenous variables before the simulation period, intercepts and equation residuals. It measures which part of the realizations of the endogenous variables cannot be explained by the exogenous variables in the simulation period. As said, we cannot reduce the average growth rates and levels to their fundamentals. Therefore, we have arbitrarily fixed the average contribution of the variables of the group rest over the simulation period at zero. For the same reason, we have put the average contribution of either the tax ratio or the liquidity ratio over the simulation period at zero.

In Tables 1-4, figures are shown for the realizations of the four different variables and the contributions made by various exogenous variables for the period 1966-1989 and the three subperiods 1966-1973, 1974-1981 and 1982-1989. Furthermore, the columns 5 and 6 contain differential growth rates, defined as the growth rate in a specific subperiod minus the growth rate in the preceding subperiod. The upper parts of the tables confront the realized values in the different subperiods with the contributions made by the group of government variables, the group of external variables, and the rest group. The middle parts decompose the contributions made by the group of government variables into the contributions of the different variables in this group. The lower parts do the same for the group of external variables.

\section{Output Growth}

Table 1 pertains to output growth. All figures refer to average growth rates. As the table shows, output growth amounted to an average of two percent in 1974-1981, more than three percentage points lower than the growth rate during 1966-1973. As column 5 of the table indicates, half of the slowdown in output growth can be attributed to government policy. The other half is due to external developments. The decelerating growth in world trade was the main external factor. The most important internal factors were the deceleration in the growth of government expenditure and public investment, besides the increase in the tax burden and the reduction of the liquidity ratio. The deceleration in the increase 
TABLE 1 - CONTRIBUTIONS TO OUTPUT GROWTH

\begin{tabular}{|c|c|c|c|c|c|c|}
\hline & $\begin{array}{l}\text { (1) } \\
1966-1989\end{array}$ & $\begin{array}{l}(2) \\
1966-1973\end{array}$ & $\begin{array}{l}(3) \\
1974-1981\end{array}$ & $\begin{array}{l}(4) \\
1982-1989\end{array}$ & $\begin{array}{l}(5) \\
(3)-(2)\end{array}$ & $\begin{array}{l}(6) \\
(4)-(3)\end{array}$ \\
\hline Realization & 3.15 & 5.32 & 1.97 & 2.17 & -3.35 & 0.20 \\
\hline Government & 1.04 & 2.08 & 0.51 & 0.54 & -1.57 & 0.03 \\
\hline External & 2.11 & 3.19 & 1.33 & 1.82 & -1.86 & 0.49 \\
\hline Rest & 0.00 & 0.05 & 0.13 & -0.19 & 0.08 & -0.32 \\
\hline$a g$ & -0.03 & -0.07 & -0.05 & 0.03 & 0.02 & 0.08 \\
\hline$g d r$ & -0.09 & -0.32 & 0.20 & -0.15 & 0.52 & -0.35 \\
\hline ig & 0.61 & 1.05 & 0.64 & 0.13 & -0.41 & -0.51 \\
\hline$m y$ & 0.55 & 0.72 & 0.33 & 0.60 & -0.39 & 0.27 \\
\hline$m$ & 0.27 & 0.30 & 0.09 & 0.43 & -0.21 & 0.34 \\
\hline$p k$ & -0.00 & -0.03 & 0.07 & -0.05 & 0.10 & -0.12 \\
\hline$v p b$ & 0.04 & 0.02 & -0.04 & 0.13 & -0.06 & 0.17 \\
\hline$m d r$ & -0.95 & -1.23 & -1.08 & -0.55 & 0.15 & 0.53 \\
\hline ty & 0.00 & 0.30 & -0.21 & -0.09 & -0.51 & 0.12 \\
\hline$\underline{a}$ & $\underline{0.65}$ & 1.34 & 0.56 & $\underline{0.06}$ & -0.78 & $=0.50$ \\
\hline Government & $\overline{1.04}$ & 2.08 & $\overline{0.51}$ & 0.54 & -1.57 & 0.03 \\
\hline as & 0.07 & 0.01 & 0.15 & 0.05 & 0.14 & -0.10 \\
\hline$z i e k$ & 0.05 & 0.07 & 0.06 & 0.03 & -0.01 & -0.03 \\
\hline$u b$ & -0.18 & -0.06 & -0.37 & -0.11 & -0.31 & 0.26 \\
\hline$r$ & -0.02 & 0.01 & -0.05 & -0.01 & -0.06 & 0.04 \\
\hline$m w$ & 2.18 & 3.16 & 1.56 & 1.81 & -1.60 & 0.25 \\
\hline pcpy & $\underline{0.01}$ & -0.00 & -0.02 & $\underline{0.05}$ & -0.02 & $\underline{0.07}$ \\
\hline External & 2.11 & 3.19 & 1.33 & $\overline{1.82}$ & -1.86 & $\overline{0.49}$ \\
\hline
\end{tabular}

in the average and marginal tax and social security rate of employees provided some compensation, but insufficient to prevent a decline in the contribution of government policy to output growth.

The eighties show a moderate improvement in comparison with the preceding period. From 1982 to 1989 output grew about 2.2 percent per annum on average. The steady development of world trade was a major factor in explaining the recovery. It boosted output growth with 0.3 percentage points per year. Government policy made a positive contribution too, albeit a very small one. The changes in tax policies that occurred in the second half of the eighties exerted a positive impact. Specifically, the lowering in the overall tax burden, the cut in the rate of profit taxation, but, most importantly, the lowering in the increase in marginal tax and social security contribution rates contributed to a higher growth rate. However, the deceleration of the growth in public investment and government expenditure offset the positive effect. 


\section{Employment Growth}

Table 2 contains the calculations that pertain to employment. From 1966-1973 to 1974-1981 employment measured in labour years declined (in terms of both the growth rate and level). This tendency can mainly be attributed to government policy. Public investment, government expenditure, and monetary factors are found to be major factors behind the worsening employment performance. These policy variables accounted for 1.3 percentage points of the 0.5 percentage points decline in employment growth. External factors also played a role. The deceleration in world trade growth accounted for a growth reduction of 0.5 percentage points. Furthermore, decreasing labour supply growth contributed to the fall of the employment growth rate. However, the model attributes more than one percentage point to rest, implying that a significant part of the employment differential growth rate remains unexplained.

From 1982 on, employment recovered. This recovery cannot be attributed to

TABLE 2 - CONTRIBUTIONS TO EMPLOYMENT GROWTH

\begin{tabular}{|c|c|c|c|c|c|c|}
\hline & $\begin{array}{l}(1) \\
1966-1989\end{array}$ & $\begin{array}{l}(2) \\
1966-1973\end{array}$ & $\begin{array}{l}(3) \\
1974-1981\end{array}$ & $\begin{array}{l}(4) \\
1982-1989\end{array}$ & $\begin{array}{l}(5) \\
(3)-(2)\end{array}$ & $\begin{array}{l}(6) \\
(4)-(3)\end{array}$ \\
\hline Realization & 0.13 & 0.28 & -0.22 & 0.33 & -0.50 & 0.55 \\
\hline Government & -1.22 & -0.35 & -1.59 & -1.71 & -1.24 & -0.12 \\
\hline External & 1.35 & 1.69 & 1.11 & 1.25 & -0.58 & 0.14 \\
\hline Rest & 0.00 & -1.06 & 0.27 & 0.79 & 1.33 & 0.52 \\
\hline$a g$ & -0.12 & -0.13 & -0.18 & -0.04 & -0.05 & 0.14 \\
\hline$g d r$ & -0.34 & -0.57 & -0.34 & -0.11 & 0.23 & 0.23 \\
\hline ig & 0.81 & 1.20 & 0.89 & 0.33 & -0.31 & -0.56 \\
\hline$m y$ & 0.00 & 0.33 & -0.17 & -0.15 & -0.50 & 0.02 \\
\hline$m$ & 0.12 & 0.37 & 0.20 & 0.42 & -0.17 & 0.22 \\
\hline$p k$ & -0.02 & -0.04 & 0.15 & -0.16 & 0.19 & -0.31 \\
\hline$v p b$ & 0.02 & -0.01 & -0.04 & 0.11 & -0.03 & 0.15 \\
\hline$m d r$ & -0.49 & -0.52 & -0.56 & -0.38 & -0.04 & 0.18 \\
\hline ty & -1.68 & -1.55 & -1.77 & -1.72 & -0.22 & 0.05 \\
\hline$\underline{a}$ & $\underline{0.26}$ & $\underline{0.57}$ & $\underline{0.23}$ & $-\underline{0.01}$ & -0.34 & -0.24 \\
\hline Government & -1.22 & -0.35 & -1.59 & -1.71 & -1.24 & -0.12 \\
\hline as & 0.49 & 0.61 & 0.32 & 0.53 & -0.29 & 0.21 \\
\hline ziek & -0.00 & -0.04 & -0.17 & 0.20 & -0.13 & 0.37 \\
\hline$u b$ & 0.03 & -0.11 & 0.28 & -0.07 & 0.39 & -0.35 \\
\hline$r$ & 0.00 & -0.01 & 0.02 & -0.01 & 0.03 & -0.03 \\
\hline$m w$ & 0.83 & 1.23 & 0.68 & 0.58 & -0.55 & -0.10 \\
\hline$p c p y$ & $\underline{0.00}$ & $\underline{0.01}$ & -0.03 & $\underline{0.02}$ & $=0.04$ & $\underline{0.05}$ \\
\hline External & 1.35 & 1.69 & 1.11 & 1.25 & -0.58 & 0.14 \\
\hline
\end{tabular}


government policy. The contribution of government policies to employment growth is more negative in 1982-1989 than in 1974-1981, due to decreasing growth rates of public consumption and public investment. Supply-side factors such as the marginal and average tax and social security contribution rates exerted a positive effect, but not large enough to fully compensate the negative impact of the public expenditure policies.

Furthermore, the figures point to an employment-increasing effect from labour supply. Again, a significant part of the change in employment growth is left unexplained. We think that the low explanatory power of the model as to employment growth is related to the unsatisfying forecasting ability of the model regarding the labour share in output. The implication of this argument is that a large part of the increase in the employment growth rate from 1974-1981 to 1982-1989 is to be attributed to the policies of wage moderation. Next, the positive relationship between employment and the tax and social security contribution rates may have some relevance. With endogenous labour supply, the

TABLE 3 - CONTRIBUTIONS TO THE INVESTMENT RATIO

\begin{tabular}{|c|c|c|c|c|c|c|}
\hline & $\begin{array}{l}(1) \\
1966-1989\end{array}$ & $\begin{array}{l}(2) \\
1966-1973\end{array}$ & $\begin{array}{l}(3) \\
1974-1981\end{array}$ & $\begin{array}{l}(4) \\
1982-1989\end{array}$ & $\begin{array}{l}(5) \\
(3)-(2)\end{array}$ & $\begin{array}{l}(6) \\
(4)-(3)\end{array}$ \\
\hline Realization & 0.03 & -0.11 & -0.58 & 0.77 & -0.47 & 1.35 \\
\hline Government & 0.05 & -0.13 & -0.39 & 0.66 & -0.26 & 1.05 \\
\hline External & -0.03 & 0.02 & -0.18 & 0.07 & -0.20 & 0.25 \\
\hline Rest & 0.00 & -0.01 & -0.01 & 0.03 & 0.00 & 0.04 \\
\hline$a g$ & 0.00 & -0.01 & 0.01 & 0.00 & 0.02 & -0.01 \\
\hline$g d r$ & 0.01 & -0.02 & 0.06 & -0.02 & 0.08 & -0.08 \\
\hline ig & -0.05 & 0.18 & -0.17 & -0.17 & -0.35 & 0.00 \\
\hline$m y$ & -0.01 & -0.12 & -0.17 & 0.25 & -0.05 & 0.42 \\
\hline$m$ & 0.02 & -0.06 & -0.06 & 0.17 & 0.00 & 0.23 \\
\hline$p k$ & -0.01 & -0.00 & -0.12 & 0.09 & -0.12 & 0.21 \\
\hline$v p b$ & 0.01 & -0.02 & -0.01 & 0.07 & 0.01 & 0.08 \\
\hline$m d r$ & 0.11 & 0.01 & 0.09 & 0.24 & 0.08 & 0.15 \\
\hline ty & 0.00 & -0.02 & 0.01 & 0.01 & 0.03 & 0.00 \\
\hline$a$ & -0.03 & -0.07 & -0.03 & $\underline{0.02}$ & $\underline{0.04}$ & $\underline{0.05}$ \\
\hline Government & 0.05 & -0.13 & -0.39 & 0.66 & -0.26 & 1.05 \\
\hline as & -0.01 & -0.04 & 0.03 & -0.03 & 0.07 & -0.06 \\
\hline ziek & 0.00 & 0.05 & -0.01 & -0.04 & -0.06 & -0.03 \\
\hline$u b$ & 0.01 & 0.04 & -0.01 & -0.01 & -0.05 & 0.00 \\
\hline$r$ & -0.01 & 0.01 & -0.05 & 0.01 & -0.06 & 0.06 \\
\hline$m w$ & -0.01 & -0.02 & -0.13 & 0.12 & -0.11 & 0.25 \\
\hline pcpy & $\underline{0.00}$ & -0.01 & -0.01 & $\underline{0.03}$ & $\underline{0.00}$ & $\underline{0.04}$ \\
\hline External & $-\overline{0.03}$ & 0.02 & -0.18 & 0.07 & -0.20 & 0.25 \\
\hline
\end{tabular}


decreasing growth of marginal tax and social security contribution rates could have explained part of the rise in employment growth.

\section{Capital Accumulation}

Table 3 contains the results for capital accumulation. The table shows the realizations of the average absolute rate of increase of the investment ratio in different periods (i.e., the rate of increase in percentage points) and the contributions made by the exogenous variables.

As with output and employment, capital accumulation was more moderate during 1974-1981 than during 1966-1973. The lower rate of increase of capital accumulation in 1974-1981 is the result of government policies as well as external variables. Both categories accounted for almost half of the deteriorating investment performance. Declining public investment was the main factor behind the fall of private investment. Tax and social security contribution policies contributed positively to capital accumulation, but, again, these policies could not offset the effect of lower public investment. Furthermore, the increasing interest rate, the rise in the cost of capital and the deceleration in the growth rate of world trade played significant roles.

Investment expanded during the last subperiod under consideration. From 1982 on, the speed of capital accumulation was considerably higher than in the years before. Although internationally circumstances were favourable, the recovery was mainly the result of governmental policies. The lower increase in the marginal tax and social security contribution rate of employees boosted investment. In addition, the cut in the tax rate on profit income exerted a positive effect. ${ }^{12}$ Next, expansionary monetary policy and a lower cost of capital boosted investment activity.

\section{Labour share in output}

Table 4 contains the calculations concerning the labour share in output. The results are rather disappointing. In spite of an acceptable estimation result for this variable and plausible calculations on the basis of the structural form of the model (not presented here), the development of the labour share cannot be attributed to the exogenous variables. Consequently, we will not discuss the reduced-form calculations.

To get some idea of the factors behind the development of the labour share in output, we turn to equation (24). Calculation of the contributions of the various

12 Note that this cannot be interpreted as evidence in favour of the argument that the policies of cutting down investment subsidies and lowering the tax rate on profit income were favourable to investment. In the estimated investment equation, variables reflecting investment subsidization are not included. 
TABLE 4 - CONTRIBUTIONS TO THE LABOUR SHARE IN OUTPUT

\begin{tabular}{llllllr}
\hline & $(1)$ & $(2)$ & $(3)$ & $(4)$ & $(5)$ & \multicolumn{1}{c}{$(6)$} \\
& $1966-1989$ & $1966-1973$ & $1974-1981$ & $1982-1989$ & $(3)-(2)$ & $(4)-(3)$ \\
\hline Realization & -0.14 & 0.61 & -0.21 & -0.82 & -0.82 & -0.61 \\
Government & -0.14 & -0.16 & -0.14 & -0.09 & 0.02 & 0.05 \\
External & 0.00 & -0.00 & 0.01 & -0.01 & 0.01 & -0.02 \\
Rest & 0.00 & 0.78 & -0.08 & -0.71 & -0.86 & -0.63 \\
\hline
\end{tabular}

explanatory variables leads us to conclude that about half the decline in the labour share in output is due to excess supply on the labour market. The other half is explained by trends in labour productivity growth. For some years, labour productivity growth was accelerating, so that actual productivity growth exceeded structural productivity growth. As wage claims are partly based upon structural productivity growth, this tendency implied an additional drop in the labour share in output.

\section{CONCLUSIONS}

The empirical analysis in this paper suggests the following conclusions. First, it confirms the finding of earlier analyses (e.g., Gelauff (1986)), that world trade plays a major role in explaining economic growth in The Netherlands. The model calculations indicate that the development of world trade is by itself sufficient to guess the direction of movements in output, employment and investment in the three periods considered. For example, 1.60 percentage points of the decline by 3.35 percentage points in output growth from 1966-1973 to 1974-1981 was the result of a less favourable development of world trade. The effect of the acceleration in world trade growth from 1974-1981 to 1982-1989 was an acceleration in output growth by 0.25 percentage points on average. That the output growth in 1982-1989 was only 0.20 percentage points higher than in the previous period, was due to, among other things, low public consumption and public investment.

Second, the analysis confirms the Keynesian proposition that restrictive fiscal policies may have adverse short-term consequences for output and employment. From 1974-1981 to 1982-1989, decreasing public expenditure lowered output and employment growth by a half and a quarter of a percentage point, respectively. Obviously, this finding relates to the assumption of short-term rigidities in the markets for goods and services. If we should abandon the rigid assumption of no market clearing and if the model should allow for a terms-of-trade effect on output, the negative short-term effects of restrictive fiscal policies might be mitigated. As the alternative hypothesis of full and immediate market clearing 
is, however, not supported by empirical evidence, it seems reasonable to take a disequilibrium approach as a starting point.

We did not find evidence for the hypothesis that investment suffered from the high budget deficits and increasing overall public debt. However, two caveats are in order. First, in estimating the equations, multicollinearity problems did occur, which might explain the investment neutrality with respect to the interest rate. Second, the model did not include forward-looking behaviour of entrepreneurs. If this element has relevance for actual investment behaviour, the negative effect of high interest rates on investment in the eighties might well be offset by a positive effect stemming from moderate wage increases. Finally, one has to bear in mind that the interest rate in The Netherlands is largely determined on a global level, mitigating the effects of policies aimed at reducing domestic budget deficits.

Most interestingly, the analysis concludes that the supply side has a considerable impact on economic performance. In particular, the analysis indicates the importance of two specific supply-side factors, the first being tax and social security contribution rates and the second one being the amount of public investment. In the eighties, the gradual decline in the continuing increase of tax and social security contribution rates boosted investment. Through higher capital accumulation, it also led to additional output and employment growth. In contrast, the shift in public expenditure towards public consumption reduced the growth of investment, output and employment. During the period 1982-1989, positive effects on output and employment growth from lower increases in the marginal tax and social security contribution rate were offset by negative effects from decelerating public investment.

As regards the impact of the policy of wage moderation in the eighties, the analysis shows that it has exerted a positive effect on employment. Through higher employment, the low-wage policy also contributed to higher output and investment. The analysis suggests two reasons for the drop in the labour share in output in the eighties. The first one is the high level of unemployment. The second is the economic recovery in the eighties. This recovery boosted labour productivity and led to a drop in the labour costs per unit of output.

\section{REFERENCES}

Aschauer, D.A. (1989), 'Does Public Capital Crowd Out Private Capital?', Journal of Monetary Economics, 24, pp. 171-188.

Barro, R.J. (1990), 'Government Spending in a Simple Model of Endogenous Growth,' Journal of Political Economy, 98, pp. 103-125.

Bomhoff, E.J. (1991), 'Beleidsimplicaties van een onzekere reële rente,' in: A. Knoester and H. Visser (eds.), De hoge reële rente en de Nederlandse economie, Preadviezen 1991, Koninklijke Vereniging voor de Staathuishoudkunde, Leiden/Antwerpen, pp. 71-82.

Broer, D.P. (1981), A Vintage Model of the Firm, Discussion Paper no. 8104 G, Institute of Economic Research, Erasmus University, Rotterdam. 
Fase, M.M.G., P. Kramer and W.C. Boeschoten (1990), MORKMON II: Het DNB kwartaalmodel voor Nederland, Monetaire Monografieën, no. 11, De Nederlandsche Bank, Amsterdam.

Ford, R. and P. Poret (1991), 'Infractructure and Private Sector Productivity,' OECD Economic Studies, no. 17, Autumn, pp. 63-89.

Gelauff, G.M.M. (1986), Het belang van de internationale stagflatie en de binnenlandse reactie daarop voor de Nederlandse economische ontwikkeling in 1973-1984; een cliometrische analyse met FK'85, Onderzoeksmemorandum no. 18, Centraal Planbureau, Den Haag.

Hall, R.E. and D.W. Jorgenson (1971), 'Application of the Theory of Optimum Capital Accumulation,' in: G. Fromm (ed.), Tax Incentives and Capital Spending, The Brookings Institution, Washington, pp. 9-60.

King, R.G. and S. Rebelo (1990), 'Public Policy and Economic Growth: Developing Neoclassical Implications,' Journal of Political Economy, 98, pp. 126-150.

Kooiman, P. (1986), Some Empirical Models for Markets in Disequilibrium, PhD Thesis, Erasmus University, Rotterdam.

Krapels, F.J., J. van Sinderen and J.P. Verbruggen (1989), Het Sigma-model; beschrijving van enkele varianten, Working Paper, Ministerie van Economische Zaken, Den Haag.

Kuipers, S.K., B.W.A. Jongbloed, G.A. Kuper and E. Sterken (1988), CESAM: Het CCSO-jaarmodel van de Nederlandse economie, Groningen.

Ram, R. and D.D. Ramsey (1989), 'Government Capital and Private Output in the United States,' Economics Letters, 30, pp. 223-226.

Romer, P.M. (1986), 'Increasing Returns and Long-Run Growth,' Journal of Political Economy, 94, pp. 1002-1037.

Rutten, F.W. (1985a), 'Berekeningen over economische groei en werkgelegenheid,' in: W. Begeer, C.A. Oomens and W.F.M. de Vries (eds.), Voor praktijk of wetenschap; afscheidsbundel voor prof. dr $P$. de Wolff, Centraal Bureau voor de Statistiek, Den Haag, pp. 145-172.

Rutten, F.W. (1985b), 'Investeringen, winst en werkgelegenheid: een economisch-politieke visie,' in: A. van der $Z$ wan (ed.), Nederland in zaken: investeren, winst en werkgelegenheid, Utrecht, pp. $290-310$.

Siebrand, J.C. (1979), Towards Operational Disequilibrium Macroeconomics, Den Haag.

Sinderen, J. van and R.J. Mulder (1988), 'Een eerste aanzet tot modellering van de aanbodeffecten van belastingen in een empirisch macro-model voor Nederland,' Maandschrift Economie, 52, pp. 169-184.

Sinderen, J. van (1993), 'Taxation and Economic Growth,' Economic Modelling, 10, July, pp. 285-300.

Stevenson, A.A., V. Muscatelli and M.B. Gregory (1988), Macroeconomic Theory and Stabilization Policy, Oxford.

Westerhout, E.W.M.T. and J. van Sinderen (1992), The Contribution of Tax and Expenditure Policies to Economic Growth in The Netherlands: An Empirical Analysis, Discussion Paper no. 9201, Ministerie van Economische Zaken, Den Haag.

\section{Summary}

\section{THE INFLUENCE OF TAX AND EXPENDITURE POLICIES ON ECONOMIC GROWTH IN THE NETHERLANDS: AN EMPIRICAL ANALYSIS}

This paper explores the influence of government policies in explaining output, employment and investment in The Netherlands during the period 1966-1989. The paper develops an empirical macroeconomic model estimated with annual data relating to the period 1958-1989. It finds that 
restrictive fiscal policies in the eighties have had adverse short-term effects on output and employment. Furthermore, the drop in the rate of increase in tax and social security contribution rates in this period has boosted output, employment and investment. However, the shift in public expenditure from investment to consumption has exerted a negative impact on these variables, largely offsetting the positive impact of the tax policies. 